\title{
EPIDEMIOLOGICAL PROFILE OF SNAKEBITES IN MOROCCO
}

\author{
Arfaoui A (1), Hmimou R (1), Ouammi L (2), Soulaymani A (1), Mokhtari A (1), \\ Chafiq $F(2)$, Soulaymani-Bencheikh $R(2,3)$
}

(1) Laboratory of Genetics and Biometrics, Kenitra Faculty of Sciences, Ibn Tofail University, Kenitra, Morocco; (2) Poison Control and Pharmacovigilance Center of Morocco, Rabat Institute, Madinat Al Irfane, Rabat, Morocco.

ABSTRACT: The present work aims to find the epidemiological profile of snakebites in Morocco through a retrospective study of 1,423 snakebite cases that occurred between 1992 and 2007. Data were obtained from medical charts of envenomation at the Poison Control and Pharmacovigilance Center of Morocco.

Results revealed that $86 \%$ of the snakebites had occurred in rural areas and that males were significantly more affected than females at a sex ratio of 23:20. Furthermore, $35 \%$ of the bites happened during the summer, with a peak of 215 cases in June $(15.1 \%)$. We also discovered that $67.3 \%$ of the patients were bitten during the day. The age group that comprised the most agriculturally active persons, from 20 to 44 years old, was the most affected by snakebites (551 cases). In terms of evolution, patients who were at least 60 years of age $(8.89 \%)$ as well as those who were less than 10 years old $(7.50 \%)$ presented higher mortality.

According to clinical severity grades, the data revealed a $70 \%$ predominance of grade 2 cases (430). Deaths had occurred only in patients with grades 3 and 4 . Furthermore, grade 4 patients presented $100 \%$ mortality whereas grade 3 registered $10.7 \%$. The distribution of snakebites according to administrative regions in Morocco showed a predominance of the Souss-Massa-Daraa region both in terms of frequency (32\%) and mortality $(72.1 \%)$.

Our study clearly displayed the severity and extent of the snakebite problem in the country, thus revealing that public health authorities should give more attention to this serious situation.

KEY WORDS: snakebites, epidemiology, mortality, Morocco.

CONFLICTS OF INTEREST: There is no conflict.

\section{CORRESPONDENCE TO:}

AMINE ARFAOUI, Laboratory of Genetics and Biometrics, Faculty of Sciences, Ibn Tofail University, B.P. 133, Kenitra, 14000, Morocco. Phone: +212662374044. Fax: +212537329433. Email: amine_arfaoui@yahoo.fr. 


\section{INTRODUCTION}

Envenomations are frequently encountered throughout the world. It is estimated that globally at least 421,000 envenomations and 20,000 deaths occur each year due to snakebites (1). Although infrequent in Europe and North America, snake envenomations represent actually a public health concern in many developing countries, where up to 5 million bites are annually reported, leading to 45,000 deaths $(2,3)$. One million snakebites occur annually in sub-Saharan Africa, resulting in almost 20,000 deaths, whereas 4 million accidents are reported in Asian countries that led to almost 80,000 deaths $(4,5)$. Venomous snake accidents are more frequent in Australia, the habitat of some of the world's most poisonous snakes (6). Approximately $30 \%$ of the 3,000 snake species across the globe are venomous and considered dangerous to humans (7). Moreover, some species (e.g. king cobra) are capable of causing death within ten minutes (8).

The Egyptian cobra, Naja haje, is the only representative of the Elapidae family in north Africa. Furthermore, this species is represented in the Moroccan Sahara by the subspecies Naja haje legionis (Figure 1), whose presence appears to be increasingly infrequent in the Agadir-Ouarzazate-Laâyoune triangle, where it had been prominent until the last century, reaching even Figuig in the east, environs of Essaouira in the northwest, Oued Assag in the southwest and Aïn Timellousa (near the Mauritania boundaries) in the southeast (9). The puff adder, Bitis arietans (Figure 2), is found in Morocco along the strip starting in Taliouine, going through Bou-Jerif (west of Guelmin), Tarfaya, Laâyoune, Lemsid and extending up to Boudjour (9). In the regions of Marrakech and Haouz, the most common snake is Coluber hippocrepis and the most dangerous one is Vipera mauritanica (10).

Snakebites lead to various clinical pictures, depending on the snake species involved and the envenomation severity $(11,12)$. Snake toxins, containing numerous protein enzymes, may be divided into three groups: cytotoxic (Viperidae), neurotoxic (Elapidae) and hemotoxic (Colubridae) venoms (13). The cytotoxic effect leads to local pain, edema and tissue necrosis with possible coagulopathy, hypovolemic shock, renal failure and death (Figure 3). The neurotoxic outcome consists of somnolence, visual disorders and respiratory distress. The hematological toxicity can manifest through bleeding that may develop into disseminated intravascular coagulopathy (14). 
In this context, the present work aimed to find the epidemiological profile of snakebites in Morocco by means of a retrospective study of all snakebite cases that occurred between 1992 and 2007.

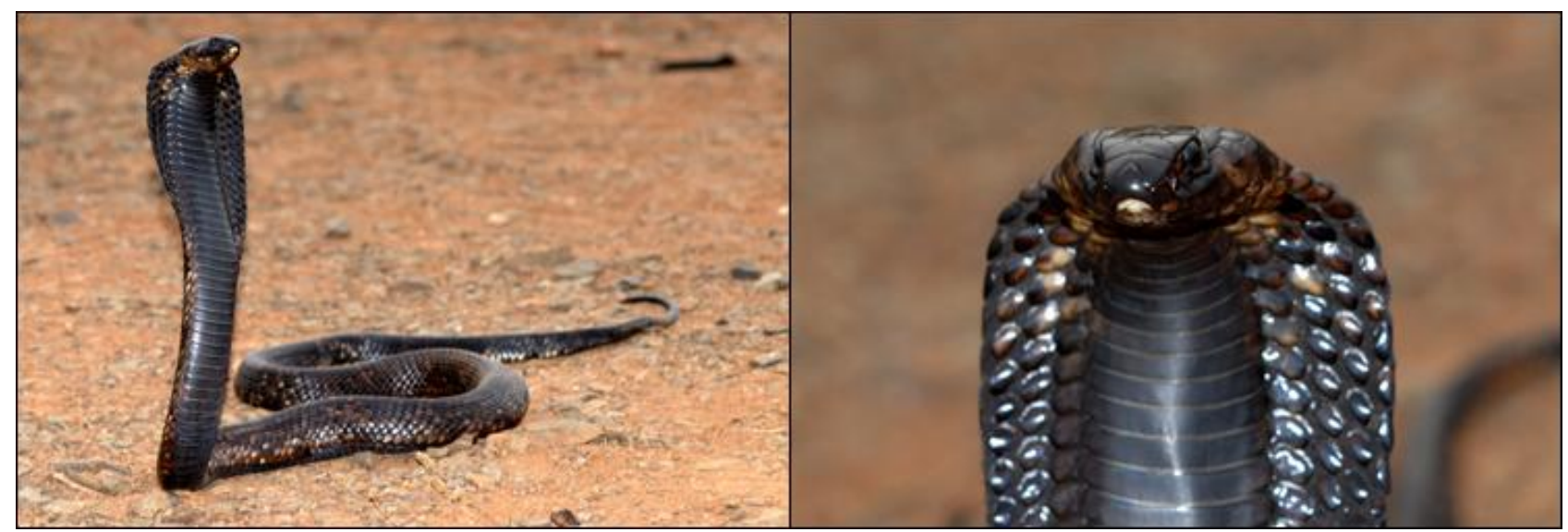

Figure 1. Egyptian cobra (Naja haje legionis), environs of Fort Bou-Jérif, west of Guelmim, Morocco (photo by M. Aymerich, 2006).

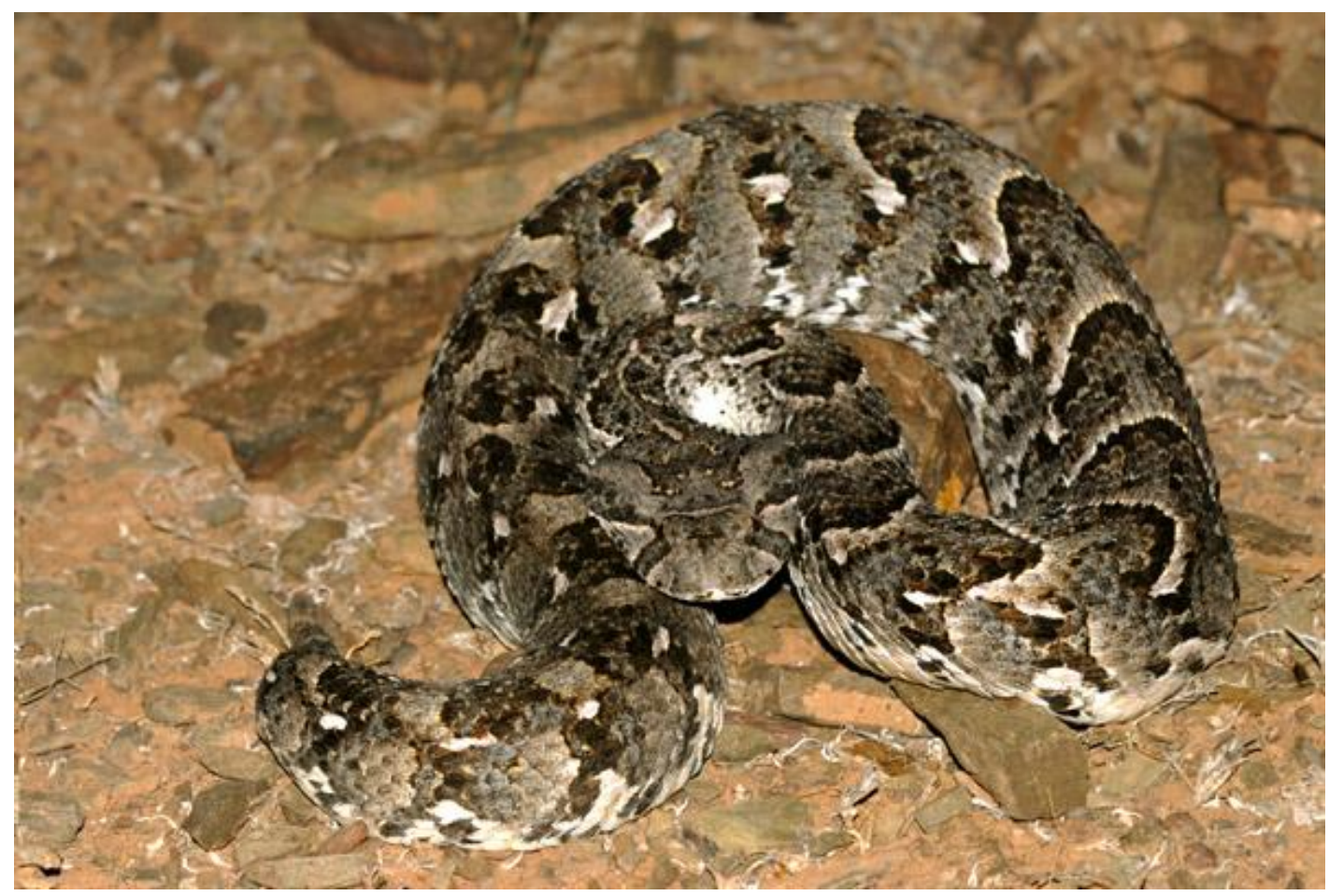

Figure 2. Puff adder (Bitis arietans), environs of Fort Bou-Jérif, west of Guelmim, Morocco (photo by M. Aymerich, 2006). 


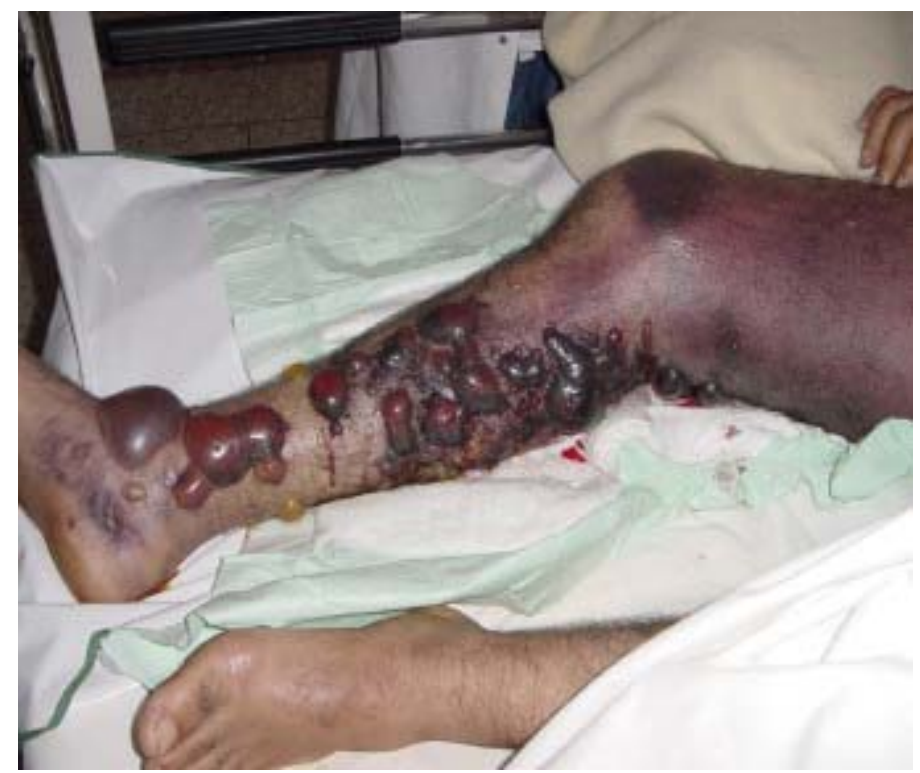

Figure 3. A 28-year-old patient admitted to the hospital after a snakebite in the region of Ouarzazate (south of Morocco).

\section{MATERIALS AND METHODS}

The present work consists of a retrospective epidemiological study based on a sample of 1,423 cases of snakebites occurred that in Morocco from 1992 to 2007. Data were obtained from envenomation charts of the Poison Control and Pharmacovigilance Center of Morocco (Toxicovigilance System).

We employed the geographic information system ArcGIS® (ESRI, USA) to obtain the geographic distribution of snakebite frequency and lethality. Analysis was carried out using Excel $®$ (Microsoft, USA) and the statistical software SPSS $®$ (SPSS Inc., USA). Descriptive statistics comprised characteristics and frequencies of the studied variables with the purpose of finding the epidemiological profile of snakebites in our series. On the other hand, analytic statistics was based on an association of tests including chi-square $\left(\chi^{2}\right)$ for the comparison of absolute frequencies; Z-test $(\varepsilon)$ for the comparison of relative frequencies; and relative risk $(R R)$ to measure the association between the presence or absence of a factor and the occurrence of an event.

Studied variables were patient-related (sex, age), snakebite-related (time and place of snakebites) and evolution-related (clinical grade, death). The number of valid data (active $\mathrm{n}$ ) is mentioned for each variable in the Results section.

The clinical gradation of snakebites and envenomations is crucial for evaluating and managing the condition of each victim (15). According to the patient condition at the time of admission, it was classified as follows (16): 
- Grade 0: bite without envenomation (absence of edema or local reaction).

- Grade 1: minor envenomation (local edema, absence of general signs).

- Grade 2: moderate envenomation (regional edema in the affected limb and/or moderate general symptoms: moderate hypotension, malaise, vomiting, abdominal pain and diarrhea).

- Grade 3: severe envenomation (extensive edema reaching the torso and/or severe general symptoms: prolonged hypotension, shock, anaphylactoid reaction and visceral trouble).

- Grade 4: extremely severe envenomation (apparent systemic involvement with blood-tinged secretions, renal failure, coma and death).

The specific lethality for a variable (region, month of bite, time of bite, age group and grade) was calculated by dividing the number of deaths in a given category by the total number of cases in this same category, and multiplying this ratio by 100.

\section{RESULTS}

The study was based on 1,423 cases of snakebites that occurred between 1992 and 2007; of which 749 patients were males (53\%) and 652 were females (47\%). The sex ratio, of 23:20, was very significant $\left(\chi^{2}=6.72 ; p<0.01\right)$. Moreover, the snakebites were significantly more frequent in rural areas, comprising 384 cases (86\%). In urban areas, in contrast, only 57 cases were registered, representing $14 \%$ of the accidents $\left(\chi^{2}=209.09 ; p<0.001\right)$.

The snakebite distribution, by administrative region of Morocco, revealed a significant predominance of the Souss-Massa-Daraa region with 447 cases (31.4\%), followed by the Marrakech-Tensift-Al Haouz region with 353 cases $(24.8 \%)$ and the MeknèsTafilalt region with 169 cases (11.9\%) (Figure 4). The snakebite dissemination among the Moroccon provinces revealed that Essaouira was the most affected locality with 321 cases $(22.6 \%)$, compared to d'Agadir Ida-Ou-Tanane $(18.4 \%)$ and Tiznit (11.7\%).

Additionally, the results showed that snakebites were more recurrent during the hot period (Figure 5). In fact, $35 \%$ of the cases had occurred in summer and $34 \%$ in spring with a peak of 215 cases in June (15.1\%). 
Regarding time, we found that most patients $(67.3 \%)$ were bitten during the day $\left(\chi^{2}=\right.$ 50.85; $p<0.001)$. The $20-44$ age group, including the most agriculturally active population, was most affected by snakebites, with 551 cases (39.7\%), followed by the 10-19 years age group with 414 cases (29.8\%). In addition, the results revealed a predominance of grade 2 that comprised $70 \%$ of the cases (430), compared to grades 3 and 0 , respectively with 105 and 50 cases (Figure 6).

The number of deaths caused by snakebites in our study was 61 , out of a valid total of 1,078 cases, which makes $5.66 \%$. Table 1 presents the specific lethality and relative risks of death for the studied variables, notably sex, age, season and grade.

Table 1. Distribution of specific lethality and relative risk (RR) according to sex, age, season and grade

\begin{tabular}{|c|c|c|c|c|c|c|}
\hline & Deaths & Total & $\begin{array}{c}\text { Specific lethality } \\
(\%)\end{array}$ & RR & \multicolumn{2}{|c|}{$\begin{array}{c}\text { Confidence interval } \\
(95 \%)\end{array}$} \\
\hline \multicolumn{7}{|l|}{$\operatorname{Sex}(n=1074)$} \\
\hline Female & 36 & 652 & 5.52 & 1.631 & 0.965 & 2.757 \\
\hline Male & 25 & 749 & 3.34 & 0.613 & 0.363 & 1.036 \\
\hline \multicolumn{7}{|l|}{ Age $(n=1067)$} \\
\hline$<10$ years & 10 & 143 & 6.99 & 1.314 & 0.651 & 2.655 \\
\hline $10-19$ years & 24 & 320 & 7.50 & 1.601 & 0.939 & 2.731 \\
\hline $20-44$ years & 14 & 418 & 3.35 & 0.454 & 0.246 & 0.837 \\
\hline $45-59$ years & 4 & 96 & 4.17 & 0.710 & 0.252 & 2.003 \\
\hline$\geq 60$ years & 8 & 90 & 8.89 & 1.735 & 0.797 & 3.778 \\
\hline \multicolumn{7}{|c|}{ Season $(n=1077)$} \\
\hline Autumn & 9 & 175 & 5.14 & 0.887 & 0.429 & 1.835 \\
\hline Winter & 11 & 149 & 7.38 & 1.401 & 0.712 & 2.758 \\
\hline Spring & 19 & 376 & 5.05 & 0.836 & 0.479 & 1.460 \\
\hline Summer & 22 & 377 & 5.84 & 1.052 & 0.614 & 1.802 \\
\hline \multicolumn{7}{|c|}{ Grade $(n=459)$} \\
\hline Grade 0 & 0 & 25 & 0 & 1.080 & 1.051 & 1.109 \\
\hline Grade 1 & 0 & 12 & 0 & 1.077 & 1.050 & 1.105 \\
\hline Grade 2 & 0 & 323 & 0 & 1.308 & 1.191 & 1.435 \\
\hline Grade 3 & 8 & 75 & 10.67 & 1.791 & 0.772 & 4.155 \\
\hline Grade 4 & 24 & 24 & 100 & 54.375 & 27.367 & 108.035 \\
\hline
\end{tabular}

The distribution of deaths according to gender showed that females presented a significantly higher specific lethality than males $\left(\varepsilon_{\text {obs }}=1.99\right)$. Similarly, the death risk among females was 1.6 times higher than in males (Table 1).

Specific lethality for age groups peaked in patients who were at least 60 years old $(8.89 \%)$ and in those who were aged less than 10 years $(7.50 \%)$. However, the difference among age groups was statistically not significant. Unsurprisingly, the two 
highest death risks were, respectively, observed in patients aged more than 60 and less than 20 years (Table 1). This could be due to the fact that the children and the elderly are physically weaker and more vulnerable to envenomation in comparison with adults.

Depending on the season, augmented specific lethality and relative risk were observed in winter with $7.38 \%$ and 1.4 respectively (Table 1). Nevertheless, seasons did not differ significantly.

In terms of evolution, deaths occurred only in patients with grades 4 and 3 , comprising respectively 24 and 8 deaths (Table 1). Thus, grade 4 patients recorded $100 \%$ lethality whereas grade 3 patients registered $10.67 \%$ mortality, so that the difference was highly significant $\left(\varepsilon_{\mathrm{obs}}=8.14\right)$. It is worth noting that the risk of death is 54.4 times higher in patients admitted with grade 4 .

Finally, Figure 7 presents the geographic distribution of lethality caused by snakebites in Morocco from 1992 to 2007. The Souss-Massa-Daraa region was the most affected by mortality, with 44 deaths (72.13\% of all snakebites), and a specific lethality of $11.28 \%$, which was significantly higher than the other regions. 


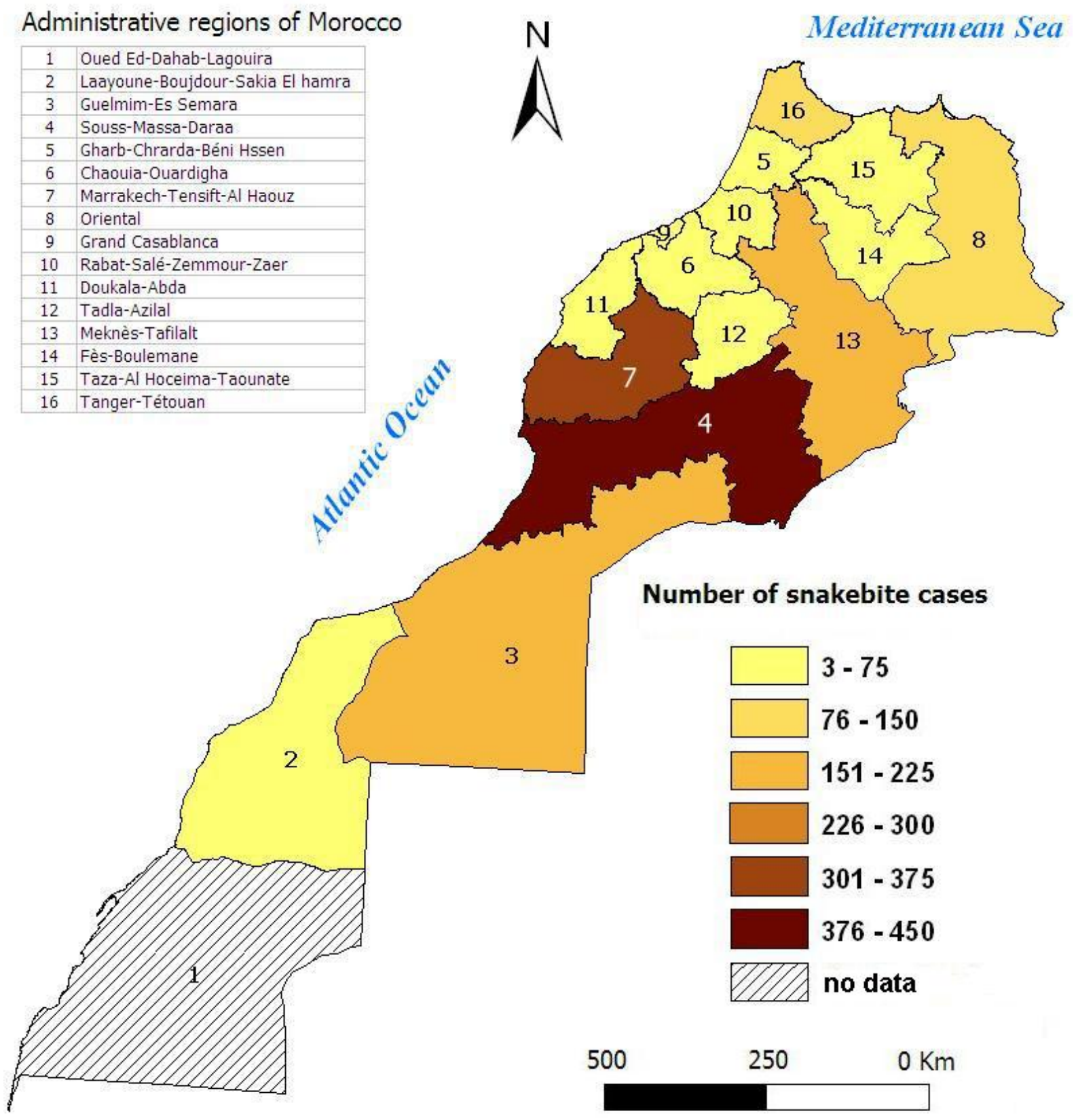

Figure 4. Distribution of snakebites by administrative region of Morocco. 
Arfaoui A et al. Epidemiological profile of snakebites in Morocco. J Venom Anim Toxins incl Trop Dis. $2009 ; 15(4): 661$

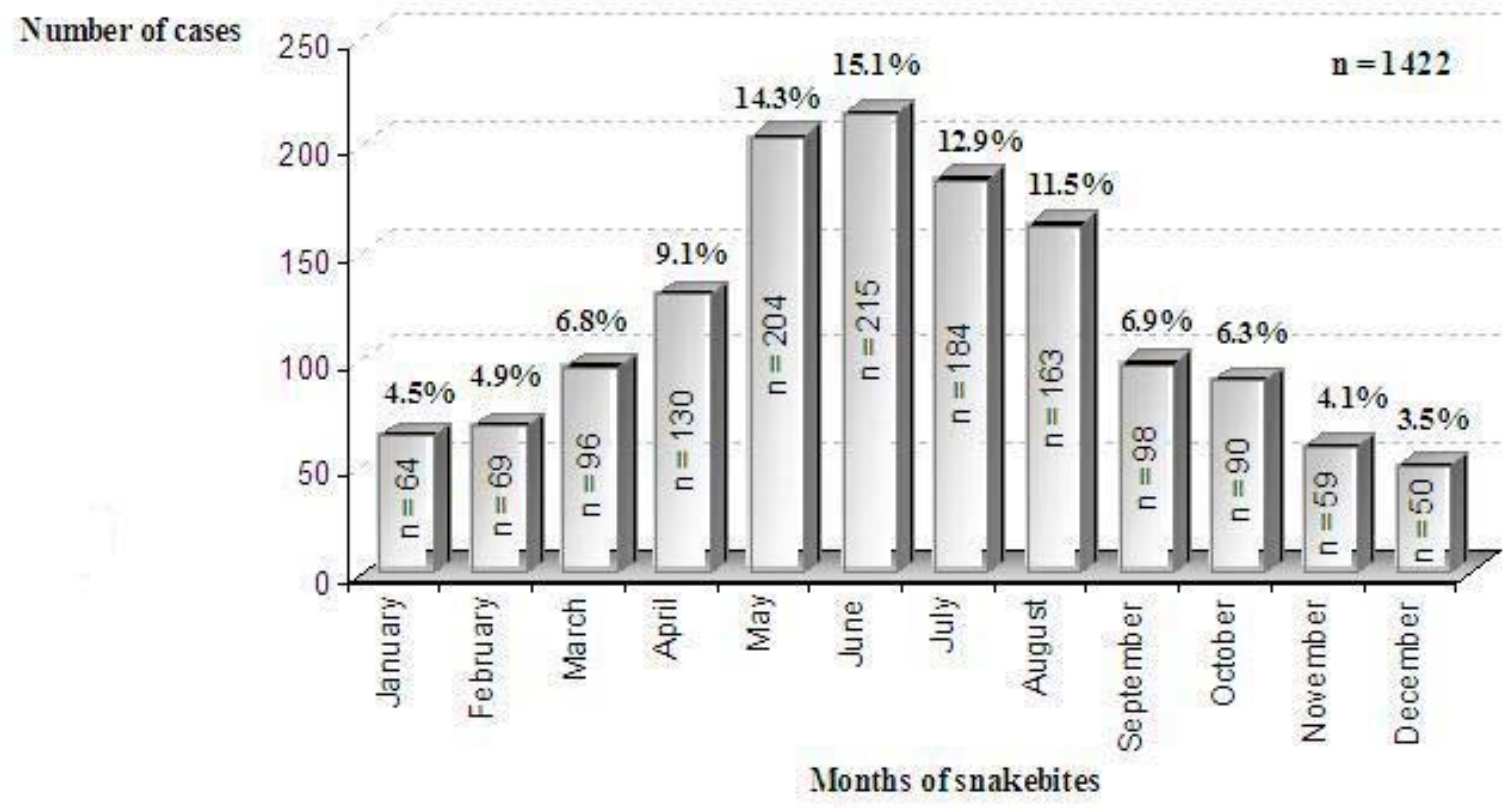

Figure 5. Distribution of snakebites according to the months of the year.

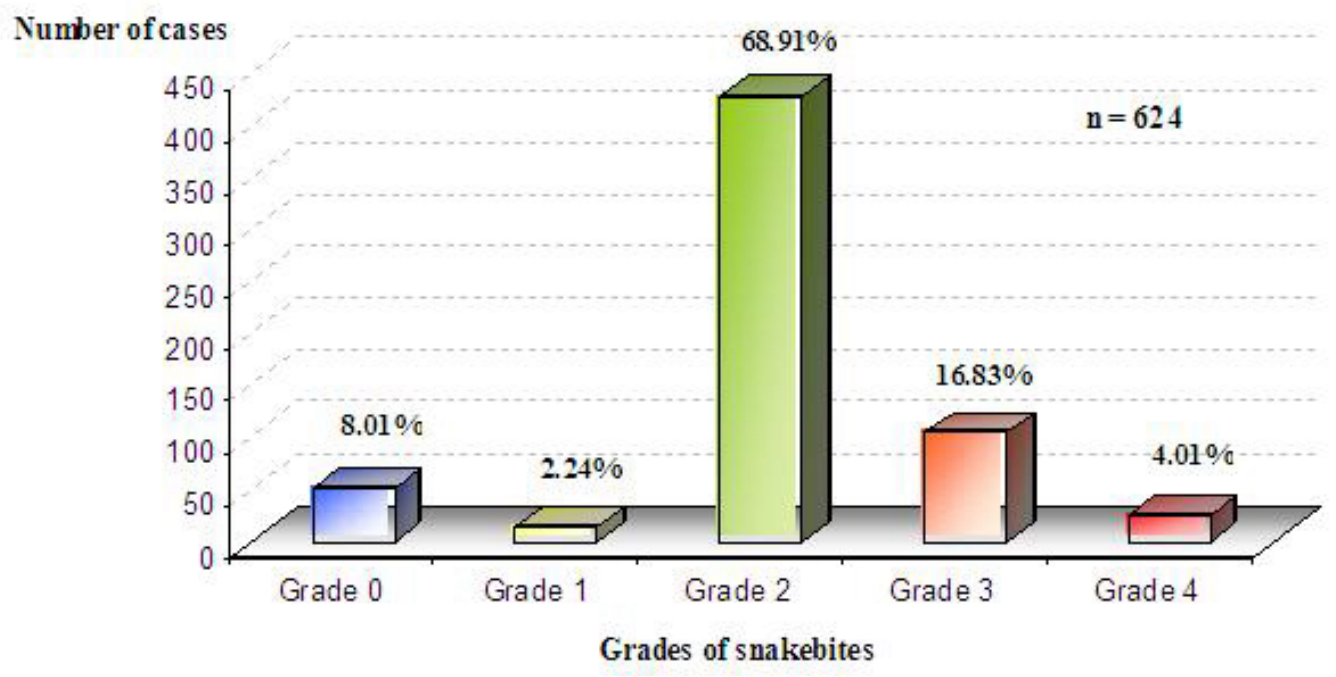

Figure 6. Distribution of snakebites by clinical grade. 


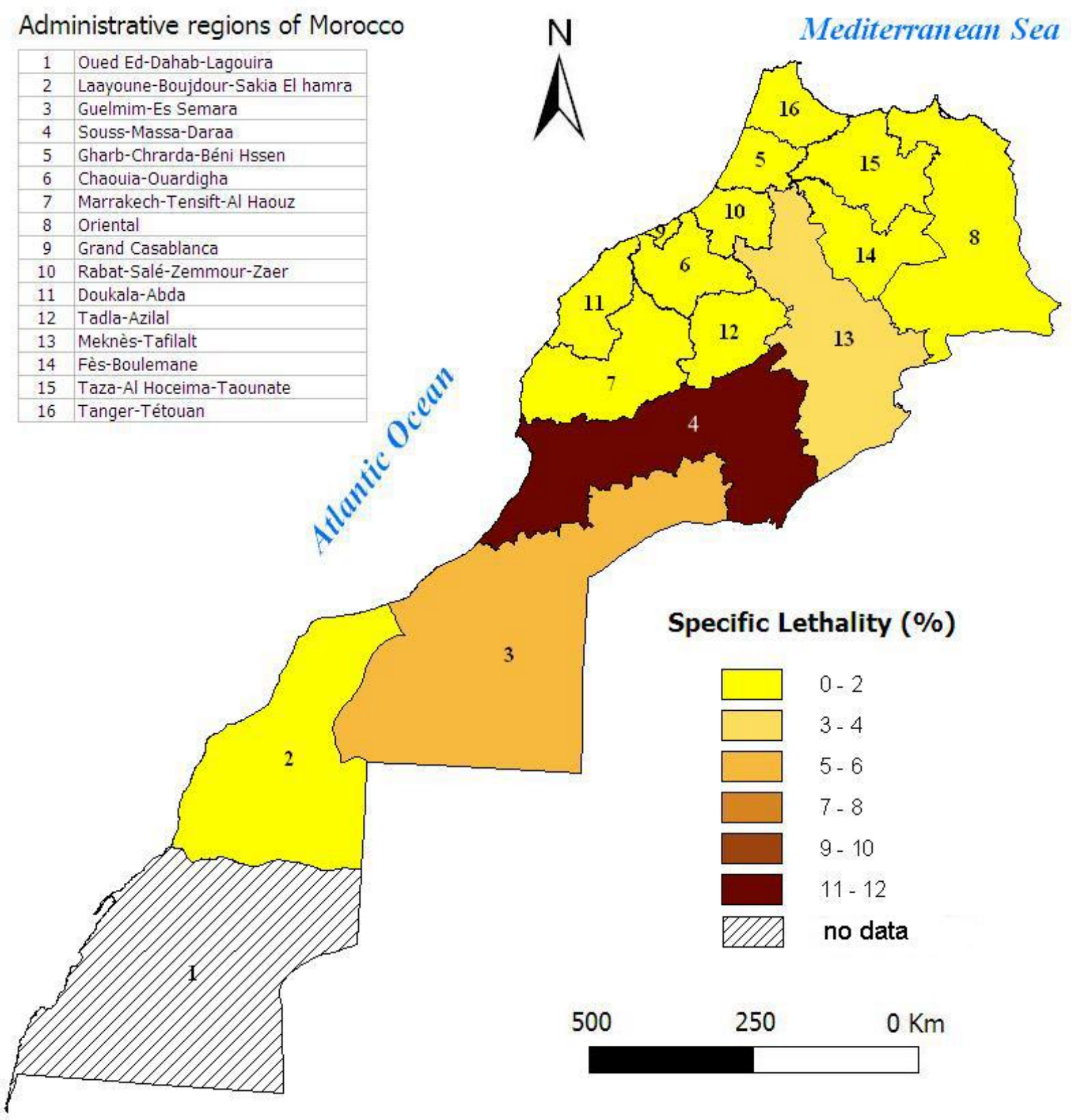

Figure 7. Distribution of snakebite specific lethality by administrative region of Morocco.

\section{DISCUSSION}

The present work showed that snakebites represent a serious public health problem in central regions of Morocco, especially in Souss-Massa-Daraa and MarrakechTensift-Al Haouz. The higher incidence in these two regions could be explained by their large population, but also by the diverse fauna of snakes living there $(13,14)$. Furthermore, the climate in this area, that varies from semiarid to arid, may play an important role in this distribution of snakes and snakebites. 
Bites were more frequent during the hot period between May and July, which can be explained by hibernation of snakes in the winter (17). This result corroborates some studies in Saudi Arabia and Brazil (18-20), but differs from others by Tchoua et al. (21), Paula Neto et al. (22) and Pacheco et al. (23), in which snakebites were reported more common between November and April.

In addition, although snake activity is generally nocturnal, most bites in our study happened during the daytime, unlike the night prevalence reported in other studies $(18,20)$. The smaller number of cases at night may be explained by the fact that human activity is mainly diurnal or that, in some regions, the staff responsible for recording admitted cases are absent during the night.

This work also demonstrated that young adults and adolescents are more affected by snakebites, mainly due to their greater exposure through outdoor activities, particularly agricultural ones $(22,24-26)$. For the same reason, males were more afflicted with bites than females. Similar results have been reported by many studies in Africa and Asia (18, 21, 26-28).

As to the mortality provoked by snakebites, our results revealed an average specific lethality of $5.66 \%$, far higher than those encountered in the literature $(27,29)$. Moreover, though considered to be mild in adults, viper bites were responsible for six deaths among victims older than 20 years of age in our study (30).

It is important to recognize that clinical signs are always connected with the envenomation degree $(31,32)$. Indeed, as reported by other groups, envenomations due to snakebites are rare, and less than $10 \%$ of these accidents are serious (31, 32). In our series, grade 2 patients were prevalent, comprising $70 \%$ of the cases without any death, whereas patients with grades 3 and 4 were few and comprised all deaths recorded in the studied period. In fact, grades 3 and 4 result either from an untreated grade 2 envenomation or from a very delayed admission to the hospital $(30,32)$.

In conclusion, although antivenoms are being produced by various laboratories on every continent, the burden of snakebite envenomation that causes both morbidity and mortality, still has a great impact on the population and on health care systems, particularly in Africa, Asia, Oceania and Latin America (33). Consequently, public health authorities, in Morocco and elsewhere, should give more attention to this serious problem. 


\section{REFERENCES}

1. Kasturiratne A, Wickremasinghe AR, Silva N, Gunawardena NK, Pathmeswaran A, Premaratna R, Savioli L, Lalloo DG, Silva HJ. The global burden of snakebite: a literature analysis and modelling based on regional estimates of envenoming and deaths. PLoS Med. 2008;5(11):1591-604.

2. Dart RC, McNally J. Efficacy, safety and use of snake antivenoms in the United States. Ann Emerg Med. 2001;37(2):181-8.

3. Warrell DA. Clinical features of envenoming from snake bites. In: Bon C, Goyffon $M$, editors. Envenomings and their treatments. Lyon: Fondation Marcel Mérieux; 1996. p. 63-76.

4. Riviere G, Bon C. Immunothérapie antivenimeuse des envenimations ophidiennes: vers une approche rationnelle d'un traitement empirique. Ann Institut Pasteur. 1999;10(2):173-82.

5. Hung DZ, Liau MY, Lin-Shian SY. The clinical significance of venom detection in patients of cobra snakebite. Toxicon. 2003;41(4):409-15.

6. Sprivulis P, Jelinek G. Toxicology: snakebite. In: Cameron P, Jelinek G, Kelly AM, Murray L, Heyworth J, editors. Textbook of adult emergency medicine. Edinburgh: Churchill Livingstone; 2000. p. 649-52.

7. Hider RC, Karlsson E, Namiraman S. Separation and purification of toxins from snake venoms. In: Harvey AL, editor. Snake Toxins. New York: Pergamon Press; 1991. p. 1-34.

8. Britt A, Burkhart K. Naja naja cobra bite. Am J Emerg Med. 1997;15(5):529-31.

9. Groupe d'Etude et de Recherche des Ecologiste Sahariens. Reptiles du Sahara et du Maroc [Internet]. Available from: http://geres-asso.org/fiches.html.

10. Roux P, Slimani T. Nouvelles données sur la répartition et l'écologie des reptiles du Maroc (la région de Marrakech: Haouz et Jebilet). Bull Inst Sci Rabat. 1992;16:122-31.

11. Bedock $B$, Blanc PL, Lassonery-Jay S. Morsure de vipères en France. Prise en charge, traitement des fortes graves. In: Réanimation et Médecine d'Urgence. Paris: Expansion Scientifique Française; 1989. p. 8-24.

12. Gold BS, Barish RA. Venomous snakebites: current concepts in diagnosis, treatment, and management. Emerg Med Clin North Am. 1992;10(2):249-67. 
13. Moujahid A, Laoutid J, Hajbi H, Baite A, Safi L. Échange plasmatique chez un patient victime d'une morsure grave de vipère. Ann Fr Anesth Reanim. 2009;28(3):258-60.

14. Pantanowitz L, Andrzejewski C. Plasma exchange therapy for victims of envenomation: is this reasonable? J Clin Apher. 2006;21(4):215-18.

15. Kaouadji K, Kaker N, Vallet B. Morsures, griffures et envenimations: conduite à tenir en urgence. EMC-Médecine. 2004;1:337-51.

16. Castanet J, Guyetant R. Atlas de répartition des amphibians et reptiles de France. Paris: Société herpétologique de France; 1989. p. 1-191.

17. Statistical Annual Reports. Directorate of Health Affairs, PHC administration. 1417:30-1.

18. Mahaba HM. Snakebite: epidemiology, prevention, clinical presentation and management. Ann Saudi Med. 2000;20(1):66-8.

19. Almeida-Santos SM, Orsi AM. Ciclo reprodutivo de Crotalus durissus e Bothrops jararaca (Serpentes, Viperidae): morfologia e função do oviduto. Rev Bras Reprod Anim. 2002;26(2):109-12.

20. Nogueira C, Sawaya RJ, Martins M. Ecology of the pitviper, Bothrops moojeni, in the Brazilian cerrado. J Herpetol. 2003;37(4):653-9.

21. Tchoua R, Raouf AO, Ogandaga A, Mouloungui C, Mbanga Loussou JB, Kombila, Ngaka Nsafu D. Analyse des envenimations par morsures de serpent au Gabon. Bull Soc Pathol Exot. 2002;95(3):188-90.

22. Paula Neto JB, Ribeiro RSP, Luz JA, Galvão M, Carvalho SMD, Haddad Junior V. Clinical and epidemiological characteristics of injuries caused by venomous snakes observed at the hospital for tropical diseases of Araguaína, Tocantins state, Brazil, from 1995 to 2000. J Venom Anim Toxins incl Trop Dis. 2005;11(4):422-32.

23. Pacheco UP, Zortéa M. Snakebites in southwestern Goiás state, Brazil. J Venom Anim Toxins incl Trop Dis. 2008;14(1):141-51.

24. Devkota UN, Steinmann JP, Shah LN. Snakebite in Nepal: a study from Sihara district, Nepal. J Nep Med Assoc. 2000;39:203-9.

25. Islam QT, Faiz MA, Azhar MA, Ekram ARMS, Alam MT. Snake bite in northern Bangladesh: a hospital based study of 68 cases. TAJ. 1999;12:135-8.

26. Sgarbi LPS, Ilias M, Machado T, Alvarez I, Barraviera B. Human envenomations due to snakebites in Marilia, state of São Paulo, Brazil. A retrospective epidemiological study. J Venom Anim Toxins. 1995;1(2):70-8. 
27. Fayomi B, Massougbodji A, Chobli M. Données épidémiologiques sur les cas de morsures de serpent déclarés au Bénin de 1994 à 2000. Bull Soc Pathol Exot. 2002;95(3):178-80.

28. Amin MR, Mamun SMH, Rashid R, Rahman M, Ghose A, Sharmin, Rahman MR, Faiz MA. Anti-snake venom: use and adverse reaction in a snake bite study clinic in Bangladesh. J Venom Anim Toxins incl Trop Dis. 2008;14(4):660-72.

29. Chippaux JP. Épidémiologie des morsures de serpent en république de côte d'Ivoire. Bull Soc Pathol Exot. 2002 ;95(3):167-71.

30. Bures E, Malin F, Fournier E, Capillon M, Robert R. Un cas mortel de morsure de vipère chez un adulte en France. La Revue de Médecine Interne. 1993;14(3):174-6.

31. Biot N, Testud F, Descotes J. Les morsures de vipère: manifestations cliniques et prise en charge. Lyon Pharm. 1994;45(5):321-5.

32. Sorkine $M$, Gilton A. Envenimations vipérines en France. Conférences d'actualisation de la Société Française d'Anesthésie-Réanimation. Paris: Masson; 1993. p. $677-87$.

33. Theakston RD, Warrell DA, Griffiths E. Report of a WHO workshop on the standardization and control of antivenoms. Toxicon. 2003;41(5):541-57. 